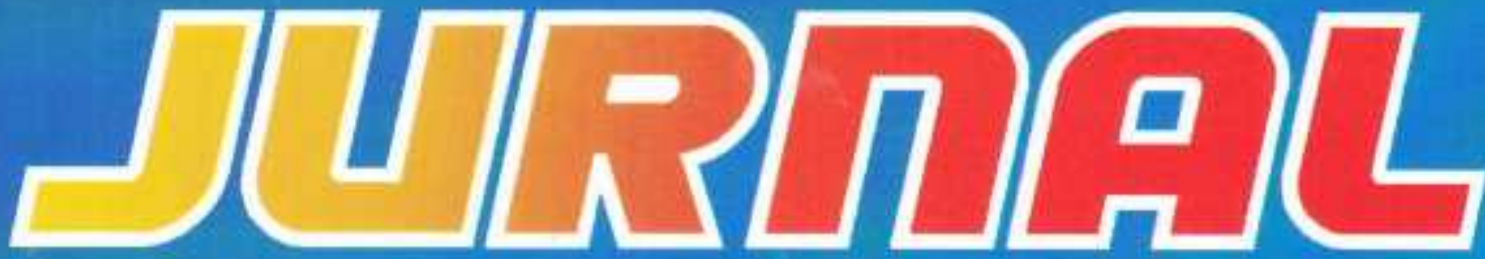

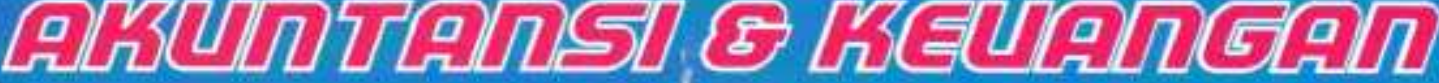

Volume 6, No. 1, Maret 2015

ISSN: $2087-2054$

Pengaruh Peran Acoount Representative Terhadap Tingkat Kepatuhan Wajib Pajak (Studi kasus pada KPP Pratama di Kota Bandar Lampung)

\section{Angrita Denziana \& Handi Sutanto}

Pengaruh Biaya Iklan Dan Biaya Penjualan Personal Terhadap Nilai Penjualan Pada PT Telekomunikasi Indonesia, Tbk.

\section{Chairul Anwar \& Rinna}

Relationship Executives Rewards With Financial Performance On Corporate Banking In Indonesia

\section{Haninun \& Putri Cagora Nisa}

Analisis Penerapan Metode Pengakuan Pendapatan Terhadap Laba Perusahaan Pada Pt. Coca Cola Distribusi Indonesia (Cabang Tanjung Karang)

\section{Herry Goenawan Soedarsa \& Surya Pandelima}

Pengaruh Tingkat Suku Bunga Simpanan Terhadap Jumlah Deposito Pada Pt. Bank Rakyat Indonesia (Persero) Tbk. Cabang Liwa

\section{Indrayenti \& Susanti}

Pengaruh Motivasi Terhadap Minat Mahasiswa Akuntansi Untuk Mengikuti Pendidikan Profesi Akuntansi (PPAK) Di Provinsi Lampung

\section{Rosmiaty Tarmizi \& Julia Restuti}

Pengaruh Kinerja Hutang Terhadap Nilai Perusahaan Pada Perusahaan Pertambangan Batubara Yang Terdaftar Di Bei Periode 2010-2013

\section{Khairudin \& Rico Tanto}

Pengaruh Profitabilitas, Ukuran Perusahaan, Debt To Equity Terhadap Ketepatan Waktu Penyampaian Laporan Keuangan (Studi Pada Perusahaan Asuransi Yang Terdaftar Di BEI)

\section{Riswan \& Tri Lestari Saputri}

Pengaruh Manajemen Laba Terhadap Kinerja Keuangan Pada Perusahaam Manufaktur Tahun 2011-2012

\section{Aminah \& Lidya Natasia Gunakan}




\section{Dewan Pembina}

Dr. Ir. M. Yusuf S. Barusman, M.B.A

Dr. Andala Rama Putra Barusman, S.E., M.A.Ec.

\section{Penanggung Jawab}

Dra. Rosmiaty Tarmizi, M.M.Akt. C.A

\section{Pimpinan Redaksi}

Dr. Angrita Denziana, S.E., M.M, Ak. C.A

\section{Sekretaris Redaksi}

Aminah, S.E., M.S.Ak

Khairudin, S.E., M.S.Ak

\section{Penyuting Ahli}

Prof. Dr. Jogiyanto Hartono, M.B.A. ( Universitas Gadjah Mada)

Tina Miniawati, S.E., M.B.A. (Universitas Trisakti)

Dr. Khomsiyah, S.E., M.M. (Universitas Trisakti)

Dr. Lindrianasari, S.E., M.Si.Akt. (Universitas Lampung)

Sujoko Efferin, Mcom (Hons), MA(Econ), Ph.D. (Universitas Surabaya)

\section{Penerbit}

Universitas Bandar Lampung

Fakultas Ekonomi dan Bisnis Program Studi Akuntansi

SENARAI-Jurnal Akuntansi \& Keuangan Terbit 2 kali setahun pada bulan Maret \&

September

Artikel yang dimuat berupa hasil riset Empiris dan telaah teoritis konsepsual yang kritis dalam kajian bidang akuntansi, auditing, perpajakan, dan keuangan.

\section{Alamat Redaksi}

Gedung G- Program Studi Akuntansi Fakultas Ekonomi dan Bisnis Universitas Bandar Lampung

Kampus A Jalan Z.A Pagar Alam No. 26 Labuan Ratu Bandar Lampung 35142

Telp: (0721) 701979, Fax: (0721) 701467, Email: Prodi.akuntansi@ubl.ac.id 


\section{JURNAL \\ AKUNTANSI \& KEUANGAN}

Volume 6, No. 1, Maret 2015

ISSN: 2087-2054

Pengaruh Peran Acoount Representative Terhadap Tingkat Kepatuhan Wajib Pajak

(Studi Kasus pada KPP Pratama di Kota Bandar Lampung)

Angrita Denziana \& Handi Sutanto

Pengaruh Biaya Iklan dan Biaya Penjualan Personal Terhadap Nilai Penjualan Pada PT

Telekomunikasi Indonesia, Tbk.

\section{Chairul Anwar \& Rinna}

Relationship Executives Rewards With Financial Performance On Corporate Banking In Indonesia

\section{Haninun \& Putri Cagora Nisa}

Analisis Penerapan Metode Pengakuan Pendapatan Terhadap Laba Perusahaan Pada PT. Coca Cola Distribusi Indonesia (Cabang Tanjung Karang)

Herry Goenawan Soedarsa \& Surya Pandelima

Pengaruh Tingkat Suku Bunga Simpanan Terhadap Jumlah Deposito Pada PT. Bank Rakyat Indonesia (Persero) Tbk. Cabang Liwa

Indrayenti \& Susanti

Pengaruh Motivasi Terhadap Minat Mahasiswa Akuntansi Untuk Mengikuti Pendidikan Profesi Akuntansi (PPAK) Di Provinsi Lampung

\section{Rosmiaty Tarmizi \& Julia Restuti}

Pengaruh Kinerja Hutang Terhadap Nilai Perusahaan Pada Perusahaan Pertambangan Batubara Yang Terdaftar Di BEI Periode 2010-2013

\section{Khairudin \& Rico Tanto}

Pengaruh Profitabilitas, Ukuran Perusahaan, Debt To Equity Terhadap Ketepatan Waktu Penyampaian Laporan Keuangan (Studi Pada Perusahaan Asuransi Yang Terdaftar Di BEI) Riswan \& Tri Lestari Saputri

Pengaruh Manajemen Laba Terhadap Kinerja Keuangan Pada Perusahaam Manufaktur Tahun 2011-2012

\section{Aminah \& Lidya Natasia Gunakan}




\section{JURNAL \\ AKUNTANSI \& KEUANGAN}

Volume 6, No. 1, Maret 2015

ISSN: 2087-2054

Daftar Isi

Halaman

$1-22$

Pengaruh Peran Acoount Representative Terhadap Tingkat Kepatuhan

Wajib Pajak (Studi kasus pada KPP Pratama di Kota Bandar Lampung)

Angrita Denziana \& Handi Sutanto

Pengaruh Biaya Iklan Dan Biaya Penjualan Personal Terhadap Nilai

Penjualan Pada PT Telekomunikasi Indonesia, Tbk.

Chairul Anwar \& Rinna

Relationship Executives Rewards With Financial Performance On

Corporate Banking In Indonesia

Haninun \& Putri Cagora Nisa

Analisis Penerapan Metode Pengakuan Pendapatan Terhadap Laba

Perusahaan Pada PT. Coca Cola Distribusi Indonesia (Cabang Tanjung

Karang)

Herry Goenawan Soedarsa \& Surya Pandelima

Pengaruh Tingkat Suku Bunga Simpanan Terhadap Jumlah Deposito Pada

PT. Bank Rakyat Indonesia (Persero) Tbk. Cabang Liwa

Indrayenti \& Susanti

Pengaruh Motivasi Terhadap Minat Mahasiswa Akuntansi Untuk

Mengikuti Pendidikan Profesi Akuntansi (PPAK) Di Provinsi Lampung

Rosmiaty Tarmizi \& Julia Restuti

Pengaruh Kinerja Hutang Terhadap Nilai Perusahaan Pada Perusahaan

Pertambangan Batubara Yang Terdaftar Di BEI Periode 2010-2013

\section{Khairudin \& Rico Tanto}

Pengaruh Profitabilitas, Ukuran Perusahaan, Debt To Equity Terhadap

Ketepatan Waktu Penyampaian Laporan Keuangan (Studi Pada Perusahaan Asuransi Yang Terdaftar Di BEI)

Riswan \& Tri Lestari Saputri

Pengaruh Manajemen Laba Terhadap Kinerja Keuangan Pada Perusahaam Manufaktur Tahun 2011-2012

Aminah \& Lidya Natasia Gunakan 


\section{JURNAL AKUNTANSI \& KEUANGAN}

Volume 6, No. 1, Maret 2015

ISSN: $2087-2054$

\section{Informasi Kebijakan dan Selingkung Berkala}

\section{Kebijakan editorial}

JURNAL Akuntansi \& Keuangan adalah sebuah berkala yang dipublikasikan oleh Universitas Bandar Lampung, yang bertujuan untuk menjadi wadah kreatifitas para akademisi, profesional, peneliti, dan mahasiswa di bidang Akuntansi dan Keuangan termasuk juga bidang Auditing, Sistem Informasi Akuntansi, Tata kelola Perusahaan, Perpajakan, Akuntansi Internasional, Akuntansi Managemen, Akuntansi Keperilakuaan, Pasar Modal dan lain sebagainya. Topik yang semakin meluas di bidang kajian riset Akuntansi diakomodir publikasinya di dalam berkala ini.

Paper yang akan dipublikasikan di dalam berkala JURNAL Akuntansi \& Keuangan harus ditulis di dalam bahasa Indonesia yang baik dan sesuai dengan EYD. Semua instrumen yang digunakan untuk memperoleh data penelitian harus dimasukkan di dalam lampiran paper penelitian, paling tidak, penulis bersedia memberikan klarifikasi atas instrumen yang digunakan saat ada permintaan dari peneliti lainnya.

\section{Sekretariat Editor Berkala}

Gedung F - Fakultas Ekonomi Universitas Bandar Lampung

Fakultas Ekonomi Program Studi Akuntansi

Kampus A Jalan Z.A. Pagar Alam No. 26 Labuhan Ratu Bandar Lampung 35142

$$
\text { Telp.: (0721) 701979, Fax.: (0721) 701467, Email: }
$$

\section{Petunjuk penulisan}

Artikel yang dikirim ke JURNAL Akuntansi \& Keuangan harus mengikuti petunjuk seperti berikut:

1. Naskah merupakan naskah asli yang belum pernah diterbitkan atau sedang dilakukan penilaian pada berkala lain. Naskah ditulis dalam bahasa Indonesia dengan jarak 1 spasi, sepanjang 20-30 halaman kertas A4 dengan tipe huruf Times New Roman.. Naskah dikirim atau diserahkan ke sekretariat JURNAL Akuntansi \& Keuangan rangkap satu disertai disket berikut dengan biodata penulis dan alamat lengkap (kantor dan rumah) pada lembaran yang terpisah dari halaman pertama artikel.

2. Judul naskah dapat ditulis dengan menggambarkan isi pokok tulisan, dan atau ditulis secara ringkas, jelas, dan menarik. 
3. Nama Penulis disertai catatan kaki tentang profesi dan lembaga tempat penulis bekerja dalam naskah yang telah diterima untuk diterbutkan.

4. Abstrak ketik satu spasi, tidak lebih dari 250 kata dalam bahasa Inggris. Abstrak memuat tujuan penelitian, isu, permasalahan, sampel dan metode penelitian, serta hasil dan simpulan (jika memungkinan).

5. Pendahuluan beriksikan uraian tentang latar belakang masalah, ruang lingkup penelitian, dan telaah pustaka yang terkait dengan permasalahan yang dikaji, serta rumusan hipotesis (jika ada). Uraian pendahuluan maksimum $10 \%$ total halaman.

6. Untuk penelitian kuantitatif,

a. Telaah Literatur dan Pengembangan Hipotesis memuat paling tidak satu buah teori yang menjadi dasar pemikiran penelitian. Hipotesis dikembangkan menggunakan asumsi dasar teori dan hasil penelitian sebelumnya. Telah literatur maksimum $40 \%$ total halaman.

b. Metodologi Penelitian meliputi uraian yang rinci tentang bahan yang digunakan, metoda yang dipilih, teknik, dan cakupan penelitian. Uraian bahan dan metoda maksimum $20 \%$ total halaman.

7. Untuk penelitian kualitatif menyesuaikan dengan metodologi kualitatif.

8. Hasil dan Pembahasan merupakan uraian obyektif dari-hasil penelitian dan pembahasan dilakukan untuk memperkaya makna hasil penelitian. Uraian hasil dan pembahasan minimum $25 \%$ total halaman.

9. Simpulan yang merupakan rumusan dari hasil-hasil penelitian. Harus ada sajian dalam satu kalimat inti yang menjadi simpulan utama. Simpulan maksimum 10\% dari keseluruhan lembar artikel.

10. Referensi (Daftar Pustaka) ditulis berurutan berdasarkan alphabetical, disusun menggunakan suku kata terakhir dari nama penulisnya, atau institusi jika dikeluarkan oleh organisasi.

a. Buku: nama penulis, tahun penerbitan, judul lengkap buku, penyunting (jika ada), nama penerbit, dan kota penerbitan.

b. Artikel dalam buku: nama penulis, tahun penerbitan, judul artikel/tulisan, judul buku, nama penyunting, kota penerbitan, nama penerbit, dan halaman.

c. Terbitan berkala: nama penulis, tahun penerbitan, judul tulisan, judul terbitan (bila disingkat, sebaiknya menggunakan singkatan yang baku), volume, nomor, dan halaman.

d. Artikel dalam internet: nama penulis, judul, dan situsnya.

e. Tabel diberi nomor dan judul dilengkapi dengan sumber data yang ditulis dibawah badan tabel, diikuti tempat dan waktu pengambilan data.

f. Ilustrasi dapat berupa gambar, grafik, diagram, peta, dan foto diberi nomor dan judul.

11. Setiap referensi yang digunakan di dalam naskah artikel menggunakan petunjuk yang dirujuk pada The Indonesian Journal of Accounting Research, sebagai berikut:

A. Kutipan dalam tubuh naskah paper harus disesuaikan dengan contoh berikut:

I. Satu sumber kutipan dengan satu penulis (Brownell, 1981).

II. Satu sumber kutipan dengan dua penulis (Frucot dan Shearon, 1991).

III. Satu sumber kutipan dengan lebih dari satu penulis (Hotstede et al., 1990).

IV. Dua sumber kutipan dengan penulis yang berbeda (Dunk, 1990; Mia, 1988).

V. Dua sumber kutipan dengan satu penulis (Brownell, 1981, 1983).

VI. Dua sumber kutipan dengan satu penulis diterbitkan pada tahun yang sama (Brownell, 1982a, 1982b). 
VII. Sumber kutipan dari lembaga harus dinyatakan dengan menggunakan akronim institusi (FASB, 1994)

B. Setiap artikel harus menulis referensi menggunakan panduan berikut:

I. Referensi harus tercantum dalam urutan abjad dari nama belakang penulis atau nama lembaga.

II. Referensi harus dinyatakan dengan urutan sebagai berikut: penulis (s) nama, tahun publikasi, judul kertas atau buku teks, nama jurnal atau penerbit dan nomor halaman. Contoh:

a) Amerika Akuntansi Association, Komite Konsep dan Standar Laporan Keuangan Eksternal. 1977. Pernyataan tentang Teori Akuntansi dan Teori Penerimaan. Sarasota, FL: AAA.

b) Demski, J. S., dan D. E. M. Sappington. 1989. Struktur hirarkis dan akuntansi pertanggungjawaban, Jurnal Akuntansi Penelitian 27 (Spring): 40-58.

c) Dye, R. B., dan R. Magee. 1989. Biaya Kontijensi untuk perusahaan audit. Kertas kerja, Northwestern University, Evansto, IL.

d) Indriantoro, N. 1993. Pengaruh Penganggaran Partisipatif Terhadap Prestasi Kerja dan Kepuasan Kerja dengan Locus of Control dan Dimensi Budaya sebagai Moderating Variabel. Ph.D. Disertasi. University of Kentucky, Lexington.

e) Naim, A. 1997. Analisis Penggunaan Akuntansi Biaya Produk Dalam Keputusan Harga oligopolistik. Jurnal Ekonomi Dan Bisnis Indonesia 12 (3): 43-50.

f) Porcano, T. M. 1984a. Keadilan distributif dan Kebijakan Pajak. Akuntansi Ulasan 59 (4): 619-636.

g) -------. 1984b. Pengaruh Persepsi Kebijakan Pajak Niat Investasi Perusahaan. The Journal of American Association Perpajakan 6 (Fall): 719.

h) Pyndyk, R. S. dan D. L. Rubinfield. 1987. Model ekonometrik \& Forecasts Ekonomi, 3rd ed. NY: McGraw-Hill Publishing, Inc.

12. Author(s) harus melampirkan CV, alamat email, alamat korespondensi dan pernyataan yang menyatakan pasal tersebut tidak sedang disampaikan kepada atau diterbitkan oleh jurnal lain dalam email tersebut dan /atau pos. 


\title{
PENGARUH PROFITABILITAS, UKURAN PERUSAHAAN, DEBT TO EQUITY TERHADAP KETEPATAN WAKTU PENYAMPAIAN LAPORAN KEUANGAN (Studi pada Perusahaan Asuransi yang Terdaftar di BEI)
}

\author{
Riswan \\ Tri Lestari Saputri \\ (Universitas Bandar Lampung) \\ email: riswan@ubl.ac.id
}

\begin{abstract}
This study aims to analyze the factors that affect the timeliness of financial reporting in insurance companies listed in Indonesia Stock Exchange. The factors examined in this study are profitability, firm size, and debt to equity as the independent variable while punctuality as the dependent variable. Based on the problems and research objectives, this study uses quantitative research. The data used in this study are secondary data from financial statements and selection of samples by using judgment sampling / purposive sampling. The results of this study revealed no significant influence of profitability, firm size, debt to equity to the timeliness of the financial statements of the insurance companies listed on the Indonesia Stock Exchange in the financial reporting data in 2010 to 2012.
\end{abstract}

keywords: profitability, financial reporting, Debt To Equity

\section{Latar Belakang Masalah}

Pelaporan keuangan merupakan wahana bagi perusahaan untuk mengkomunikasikan berbagai informasi dan pengukuran secara ekonomi mengenai sumber daya yang dimiliki serta kinerja kepada berbagai pihak yang mempunyai kepentingan atas informasi tersebut. Pelaporan keuangan mempunyai pengertian yang lebih luas dibandingkan dengan laporan keuangan. Dalam pelaporan keuangan tidak hanya laporan keuangan tetapi semua informasi yang terkait secara langsung maupun tidak langsung dengan informasi yang disediakan oleh sistem akuntansi yaitu informasi tentang sumber daya perusahaan, hutang, earnings, dan sebagainya.

Penyampaian pelaporan keuangan bagi perusahaan publik diatur tersendiri dalam UU No. 8 tahun 1995 tentang pasar modal. Bapepam mengeluarkan Lampiran Keputusan Ketua Bapepam Nomor: KEP-80/PM/1996, yang mewajibkan bagi setiap emiten dan perusahaan publik untuk menyampaikan laporan keuangan tahunan perusahaan dan laporan auditor independennya kepada Bapepam selambat-lambatnya pada akhir bulan keempat (120 hari) setelah tanggal laporan keuangan tahunan perusahaan. Namun sejak tanggal 30 September 2003, Bapepam semakin memperketat peraturan dengan dikeluarkannya Peraturan Bapepam Nomor: X.K.2, lampiran Keputusan Ketua Bapepam Nomor: KEP-36/PM/2003 tentang Kewajiban Penyampaian Laporan Keuangan Berkala, yang kemudian diperbarui dengan 
dikeluarkannya Peaturan Bapepam X.K.6, lampiran Keputusan Ketua Bapepam Nomor: KEP-134/BL/2006 tentang Kewajiban Penyampaian Laporan Tahunan Bagi Emiten dan Perusahaan Publik yang Efeknya Tercatat Di Bursa Efek Indonesia dan Di Bursa Efek Negara Lain. Hingga dikeluarkannya lampiran Keputusan Ketua Bapepam Nomor: KEP40/BL/2007 tentang Jangka Waktu Penyampaian Laporan Keuangan Berkala dan Laporan Tahunan Bagi Emiten atau Perusahaan Publik yang Efeknya Tercatat Di Bursa Efek Indonesia dan Di Bursa Efek Negara Lain.

Peraturan ini menyatakan bahwa laporan keuangan tahunan harus disertai dengan laporan Akuntan dengan pendapat yang lazim dan disampaikan kepada Bapepam selambatlambatnya pada akhir bulan ketiga (90 hari) setelah tanggal laporan keuangan tahunan. Submisi dan publikasi laporan keuangan tahunan teraudit (audited annual financial statement) dan laporan keuangan semi tahunan yang tidak teraudit (unaudited semiannual financial statement) bersifat wajib, sedangkan pengiriman laporan keuangan triwulanan hanya bersifat sukarela. Laporan keuangan harus dibuat berdasarkan Standar Akuntansi Keuangan (SAK), dan terdiri dari neraca, laporan laba rugi dan laporan arus kas, pengungkapan mengenai kebijakan akuntansi dan catatan yang menyertai laporan keuangan. Peraturan ini juga mewajibkan perusahaan mengungkapkan peristiwa penting lain dan informasi seperti merger dan akuisisi, pergantian manajemen puncak dan pergantian auditor perusahaan. Bapepam, badan pemerintah yang mengawasi pelaksanaan pasar modal di Indonesia, memberlakukan peraturan keuangan dan mengenakan sanksi bagi perusahaan yang tidak mematuhinya. Selain itu dalam Peraturan Bapepam Nomor X.K.7 lampiran Keputusan Ketua Bapepam Nomor: KEP-40/BL/2007, disebutkan bahwa batas waktu penyampaian laporan keuangan tahunan kepada Bapepam dan laporan keuangan dilakukan mengikuti ketentuan di negara lain tersebut.

\section{Teori Pendukung dan Hipotesis}

\subsection{Teori Pendukung}

\section{Teori Agensi ( Agency Theory )}

Teori keagenan adalah teori yang menjelaskan hubungan antara agen (manajemen suatu usaha) dan prinsipal (pemilik usaha). Di dalam hubungan keagenan terdapat suatu kontrak dimana si agen menutup kontrak untuk melakukan tugas-tugas tertentu bagi prinsipal, prinsipal menutup kontrak untuk memberi imbalan pada si agen. Analoginya seperti antara pemilik perusahaan dan manajemen perusahaan itu (Hendriksen, 2000). 
Pada teori keagenan (agency theory) juga dijelaskan mengenai adanya asimetri informasi antara manajer sebagai agen dan pemilik (pemegang saham) sebagai prinsipal. Asimetri informasi terjadi karena pihak manajer lebih mengetahui informasi internal dan prospek perusahaan di masa yang akan datang dibandingkan dengan pemegang saham dan stakeholder lainnya. Penyampaian laporan keuangan kepada stakeholder nantinya dapat meminimalkan asimetri informasi yang terjadi antara pihak manajer dan stakeholder karena laporan keuangan merupakan sarana pengkomunikasian informasi keuangan kepada pihakpihak di luar perusahaan (Rahmawati dkk, 2007).

\section{Teori Sinyal (Signalling Theory)}

Teori signalling menyatakan bahwa perusahaan yang berkualitas baik dengan sengaja akan memberikan sinyal pada pasar, dengan demikian pasar diharapkan dapat membedakan perusahaan yang berkualitas baik dan buruk (Hartono, 2005). Agar sinyal tersebut efektif, maka harus dapat ditangkap pasar dan dipersepsikan baik, serta tidak mudah ditiru oleh perusahaan yang berkualitas buruk (Mengginson dalam Hartono, 2005).

Pengumuman ini nantinya dapat mempengaruhi naik turunnya harga sekuritas perusahaan emiten yang melakukan pengumuman (Suwardjono,2005). Perusahaan yang mempunyai keyakinan bahwa perusahaan tersebut mempunyai prospek yang baik ke depannya akan cenderung mengkomunikasikan berita tersebut terhadap para investor (Ross dalam Mamduh Hanafi ,2004). Pada penelitian ini perusahaan yang berkualitas baik nantinya akan memberi sinyal dengan cara menyampaikan laporan keuangannya dengan tepat waktu, hal ini tidak bisa ditiru oleh perusahaan yang berkualitas buruk karena perusahaan berkualitas buruk akan cenderung tidak tepat waktu dalam menyampaikan laporan keuangannya. Pada penelitian ini sinyal yang diberikan oleh perusahaan yang berkualitas baik dianggap sebagai berita baik (good news) sedangkan sinyal yang diberikan oleh perusahaan yang berkualitas buruk dianggap sebagai berita buruk (bad news).

\subsection{Penelitian Terdahulu dan Hipotesis}

Beberapa penelitian telah dilakukan oleh para peneliti dan akademisi sebelumnya mengenai faktor-faktor yang berpengaruh terhadap ketepatan waktu pelaporan keuangan perusahaan dengan menggunakan beberapa variabel. Seperti Dyer dan Mc. Hugh (1975) dalam Oktorina dan Suharli (2005) meneliti tentang profil ketepatan waktu pelaporan dan normalitas keterlambatan dengan menggunakan 120 perusahaan di Australia periode 19651971. Hasil penelitiannya menunjukkan bahwa ukuran perusahaan, tanggal berakhirnya tahun 
buku secara signifikan berpengaruh terhadap ketepatan waktu pelaporan keuangan, sedangkan profitabilitas tidak secara signifikan mempengaruhi ketepatan waktu pelaporan.

Bandi dan Hananto (2000) melakukan penelitian tentang ketepatan waktu pelaporan keuangan dan hubungannya dengan reaksi pasar atas ketepatan waktu. Hasil penelitiannya menemukan bukti empiris bahwa keterlambatan pelaporan yang meliputi keterlambatan audit, keterlambatan pelaporan setelah audit dan keterlambatan total berdistribusi tidak normal dan menunjukkan kemiringan positif. Hal ini mengidentifikasikan bahwa pelaporan perusahaan selalu mengalami kemunduran. Selain itu, hubungan keterlambatan dengan besarnya perusahaan positif, walaupun tidak signifikan. Temuan lainnya dalam penelitian ini yaitu ketepatan waktu pelaporan antara pelaporan sebelum dan sesudah waktu yang diharapkan tidak berpengaruh terhadap harga saham.

Annisa (2004) menguji penelitian mengenai faktor-faktor yang mempengaruhi ketepatan waktu pelaporan keuangan di Bursa Efek Jakarta dengan menemukan hasil bahwa kualitas auditor, leverage financial, dan profitabilitas diduga memotivasi manajemen untuk menyampaikan laporan keuangan secara tepat waktu, hanya opini audit yang berpengaruh terhadap ketepatan waktu penyampaian laporan keuangan.

Sedangkan Saleh (2004) meneliti faktor-faktor yang berpengaruh terhadap ketepatan waktu pelaporan keuangan perusahaan manufaktur di Bursa Efek Jakarta. Adapun hasilnya menunjukkan bahwa variable item luar biasa secara signifikan berpengaruh terhadap ketepatan waktu pelaporan keuangan perusahaan-perusahaan manufaktur dan mempunyai hubungan tanda yang sesuai dengan logika atau teori. Rasio gearing, ukuran perusahaan, dan struktur kepemilikan tidak berpengaruh secara signifikan terhadap ketepatan waktu pelaporan keuangan dan mempunyai hubungan tanda yang tidak sesuai dengan logika atau teori.

Respati (2004) melakukan penelitian mengenai faktor-faktor yang berpengaruh terhadap ketepatan waktu pelaporan keuangan pada perusahaan yang terdaftar di Bursa Efek Jakarta tahun 1999 dengan sample sebanyak 266 perusahaan go public yang mempunyai data perusahaan yang lengkap dan telah didaftarkan dalam Indonesian Capital Market Directory 2000. Beliau meneliti beberapa faktor yang mempengaruhi ketepatan waktu pelaporan keuangan di Bursa Efek Jakarta yaitu debt to equity, ukuran perusahaan, profitabilitas, konsentrasi pemilikan luar, konsentrasi pemilikan dalam. Dan hasilnya adalah profitabilitas dan konsentrasi pemilikan dari pihak luar secara signifikan berpengaruh terhadap ketepatan waktu pelaporan keuangan perusahaan. 
Sedangkan pada penelitian Wirakusuma (2004) yang meneliti 132 perusahaan yang terdaftar di Bursa Efek Jakarta memperoleh hasil bahwa faktor yang mempengaruhi rentang waktu pengumuman laporan keuangan auditan ke publik adalah rentang waktu penyelesaian audit laporan keuangan, solvabilitas dan opini auditor mengenai kewajaran laporan keuangan perusahaan.

Hilmi dan Ali (2008) menguji dengan regresi logistik memperoleh hasil bahwa faktorfaktor yang mempengaruhi ketepatan waktu penyampaian laporan keuangan pada perusahaan go public yang terdaftar di Bursa Efek Jakarta periode tahun 2004 sampai dengan 2006 adalah profitabilitas, likuiditas, kepemilikan publik, dan reputasi KAP. Sedangkan variabel leverage keuangan, ukuran perusahaan, dan opini auditor tidak mempunyai pengaruh yang signifikan terhadap ketepatan waktu penyampaian laporan keuangan.

\subsection{Hipotesis}

Adapun hipotesis yang dapat diajukan pada penelitian ini adalah:

1. Profitabilitas berpengaruh terhadap ketepatan waktu penyampaiaan laporan keuangan pada perusahaan jasa asuransi yang terdaftar di Bursa Efek Indonesia.

2. Ukuran perusahaan berpengaruh terhadap ketepatan waktu penyampaiaan laporan keuangan pada perusahaan jasa asuransi yang terdaftar di Bursa Efek Indonesia.

3. Deb to Equity berpengaruh terhadap ketepatan waktu penyampaiaan laporan keuangan pada perusahaan jasa asuransi yang terdaftar di Bursa Efek Indonesia.

\section{Metodologi Penelitian}

\subsection{Sampel}

Sampel adalah sebagian dari unit-unit yang ada dalam populasi yang ciri-ciri atau karakteristiknya benar-benar diselidiki. Pada penelitian ini yang dijadikan sampel penelitian adalah perusahaan jasa asuransi yang terdaftar di Bursa Efek Indonesia yang berjumlah 11 perusahaan asuransi dan laporan keuangan yang diamati selama tiga tahun yaitu tahun 2010 hingga 2012 sehingga total sampel adalah 33 (11 perusahaan x 3 tahun). Pemilihan sampel dilakukan dengan metode pengetahuan dan pertimbangan tertentu dari peneliti terhadap objek yang akan diteliti, metode ini juga disebut judgement sampling /purposive sampling. Adapun kriteria sampel yang digunakan:

e. Laporan keuangan semua perusahaan asuransi yang beroperasi secara aktif selama tahun 2010 hingga 2012. 
f. Perusahaan asuransi yang menyajikan laporan keuangan secara lengkap yang terdaftar di Bursa Efek Indonesia pada periode 2010 hingga 2012.

g. Perusahaan asuransi yang beroperasi secara continue atau terus-menerus selama periode penelitian.

\subsection{Jenis Data}

Jenis data yang digunakan dalam penelitian ini adalah data sekunder. Data Sekunder adalah data yang diperoleh dari media internet, buku atau literatur yang berhubungan dengan pembahasan dan penelitian yang berdasarkan data penunjang lain yang kaitannya dengan permasalahan yang diteliti. Pada penelitian ini penulis mengambil data berupa laporan keuangan dari objek penelitian. Sumber data dalam penelitian ini berupa laporan tahunan (annual report) perusahaan asuransi di Bursa Efek Indonesia selama periode tiga tahun yaitu tahun 2010 hingga 2012. Data tersebut diperoleh melalui website Bursa Efek Indonesia yaitu www.idx.co.id.

\section{a. Jenis Penelitian}

Berdasarkan permasalahan dan tujuan penelitian, maka penelitian ini menggunakan jenis penelitian kuantitatif, yaitu penelitian menggunakan data sekunder berupa laporan keuangan. Sedangkan desain penelitian adalan penelitian kausalitas yang bertujuan untuk mengetahui hubungan / pengaruh dua variabel atau lebih, menguji teori, dan analisa data dengan menggunakan statistik untuk menguji hipotesis.

\subsection{Pengujian Hipotesis}

Pengujian hipotesis menggunakan uji koefisien regresi secara parsial (Uji t). Uji hipotesis ini adalah uji t-test yaitu dengan membandingkan antara $t$ hitung dengan $t$ tabel. Adapun prosedur atau langkah-langkah pengujian hipotesis sebagai berikut:

Hipotesis penelitian

Hipotesis penelitian digunakan untuk menentukan hipotesis nol (Ho) dan hipotesis alternatif (Ha).

Ho : Tidak terdapat pengaruh Profitabilitas $\left(\mathrm{X}_{1}\right)$ terhadap Ketepatan Waktu Penyampaian Laporan Keuangan (Y)

$\mathrm{H}_{1}$ : Terdapat pengaruh Profitabilitas $\left(\mathrm{X}_{1}\right)$ terhadap Ketepatan Waktu Penyampaian Laporan Keuangan (Y) 
Ho : Tidak terdapat pengaruh Ukuran Perusahaan $\left(\mathrm{X}_{2}\right)$ terhadap Ketepatan Waktu Penyampaian Laporan Keuangan (Y)

$\mathrm{H}_{2}$ : Terdapat pengaruh Ukuran Perusahaan $\left(\mathrm{X}_{2}\right)$ terhadap Ketepatan Waktu Penyampaian Laporan Keuangan (Y)

Ho : Tidak terdapat pengaruh Debt to Equity $\left(\mathrm{X}_{3}\right)$ terhadap Ketepatan Waktu Penyampaian Laporan Keuangan (Y)

$\mathrm{H}_{3}$ : Terdapat pengaruh Debt to Equity $\left(\mathrm{X}_{3}\right)$ terhadap Ketepatan Waktu Penyampaian Laporan Keuangan (Y)

2. Hipotesis Statistik

Pengujian hipotesis statistik menggunakan rumus :

Ho : $\beta_{1}=\beta_{2}=\beta_{3}=0$

Ha: $\beta_{1} \neq \beta_{2} \neq \beta_{3} \neq 0$

3. Kesimpulan Hipotesis

Apabila t hitung $<\mathrm{t}$ tabel maka Ho diterima (Ha ditolak)

Apabila $t$ hitung $>\mathrm{t}$ tabel maka Ho ditolak (Ha diterima)

\subsection{Variabel Penelitian}

Variabel penelitian pada dasarnya adalah segala sesuatu yang berbentuk apa saja yang ditetapkan oleh peneliti untuk dipelajari, sehingga diperoleh informasi tentang hal tersebut, kemudian ditarik kesimpulannya. Variabel yang digunakan dalam penelitian ini adalah :

1. Variabel bebas (independent variable),yaitu variabel yang mempengaruhi variable lain.

Dalam penelitian ini yang menjadi variabel bebas yaitu:

a. Profitabilitas $\left(\mathrm{X}_{1}\right)$ Profitabilitas merupakan indikator keberhasilan perusahaan dalam menghasilkan laba. Semakin tinggi kemampuan perusahaan dalam menghasilkan laba maka semakin tinggi pula tingkat efektifitas manajemen tersebut. Profitabilitas dapat diukur menggunakan Return on Asset (ROA).

b. Ukuran Perusahaan $\left(\mathrm{X}_{2}\right)$ Ukuran perusahaan merupakan variabel yang digunakan untuk mengukur seberapa besar atau kecilnya sampel perusahaan yang digunakan. Ukuran perusahaan dapat dinilai dari total nilai aktiva, total penjualan, jumlah tenaga kerja. Pada penelitian ini, ukuran perusahaan diukur dengan menggunakan total asset.

c. Debt to Equity $\left(\mathrm{X}_{3}\right)$ Debt ratio merupakan rasio yang digunakan untuk mengukur perbandingan antara total utang dengan total modal. 
2. Variabel terikat (dependent), yaitu variabel yang dipengaruhi oleh variabel yang lain.

Dalam penelitian ini variabel terikat yaitu :

Ketepatan Waktu Penyampaian Laporan Keuangan (Y):

Variabel terikat ini diukur berdasarkan tanggal penyampaian laporan keuangan tahunan auditan ke Bapepam. Variabel ini diukur dengan menggunakan variabel dummy dengan kategorinya yaitu bagi perusahaan yang memiliki ketepatan waktu (menyampaikan laporan keuangannya kurang dari 90 hari setelah akhir tahun atau sebelum tanggal 30 Maret) masuk kategori 1 dan perusahaan yang tidak tepat waktu (menyampaikan laporan keuangannya lebih dari 90 hari setelah akhir tahun atau setelah tanggal 30 Maret) masuk kategori 0 .

\section{Pembahasan Dan Hasil Penelitian}

\subsection{Deskripsi Setiap Variabel}

Berdasarkan kriteria sampel yaitu semua perusahaan asuransi yang beroperasi secara aktif selama tahun 2010 hingga 2012, dan menyajikan laporan keuangan secara lengkap terus-menerus, maka ditetapkan sebelas perusahaan yang layak dijadikan sampel yaitu sebagai berikut:

Tabel 1

\section{Daftar Perusahaan Asuransi di BEI yang Menjadi Sampel Penelitian}

\begin{tabular}{|c|l|l|}
\hline No & \multicolumn{1}{|c|}{ Nama Perusahaan } & \multicolumn{1}{|c|}{ Kode } \\
\hline 1 & Asuransi Bina Dana Artha, Tbk & ABDA \\
2 & Asuransi Harta Aman Pratama, Tbk & AHAP \\
3 & Asuransi Multi Artha Guna, Tbk & AMAG \\
4 & Asuransi Bintang, Tbk & ASBI \\
5 & Asuransi Dayin Mitra, Tbk & ASDM \\
6 & Asuransi Jasa Tania, Tbk & ASJT \\
7 & Asuransi Ramayana, Tbk & ASRM \\
8 & Lippo General Insurance, Tbk & LPGI \\
9 & Maskapai Reasuransi Indonesia, Tbk & MREI \\
10 & Panin Insurance, Tbk & PNIN \\
11 & Panin Financial, Tbk & PNLF \\
\hline
\end{tabular}

Sumber: Bursa Efek Indonesia, 2013 
Kemudian semua data yang diperoleh pertahun dari tahun 2010 hingga 2012, maka terdapat 33 data yang disajikan sebagai berikut:

Tabel 2

Data Variabel Penelitian

\begin{tabular}{|c|c|c|c|c|c|}
\hline Perusahaan & Tahun & Profitabilitas & Uk. Perusahaan & $\begin{array}{l}\text { Debt to } \\
\text { Equity }\end{array}$ & T.Waktu \\
\hline \multirow[t]{3}{*}{ ABDA } & 2010 & 45.296 .577 .000 & 845.778 .581 .000 & 3,283316098 & 0 \\
\hline & 2011 & 87.622 .183 .000 & 1.426 .730 .624 .000 & 2,526050431 & 1 \\
\hline & 2012 & 118.689 .198 & 1.796 .429 .549 .000 & 1,890663516 & 1 \\
\hline \multirow[t]{3}{*}{ AHAP } & 2010 & 9.413 .123 .942 & 126.549 .735 .522 & 1,162195263 & 1 \\
\hline & 2011 & 14.430 .725 .283 & 210.216 .177 .607 & 1,987356761 & 1 \\
\hline & 2012 & 16.548 .711 .550 & 252.378 .052 .864 & 2,052696672 & 1 \\
\hline \multirow[t]{3}{*}{ AMAG } & 2010 & 59.362 .441 .000 & 654.356 .727 .000 & 0,864451161 & 1 \\
\hline & 2011 & 95.466 .163 .000 & 1.080 .639 .784 .000 & 0,692332902 & 1 \\
\hline & 2012 & 147.142 .681 .000 & 1.349 .457 .388 .000 & 0,763485027 & 1 \\
\hline \multirow[t]{3}{*}{ ASBI } & 2010 & 2.676 .579 .000 & 243.601 .400 .000 & 1,587039078 & 1 \\
\hline & 2011 & 9.119 .219 .000 & 294.199 .390 .000 & 2,102789963 & 1 \\
\hline & 2012 & 28.087 .634 .000 & 369.709 .147 .000 & 2,100191434 & 1 \\
\hline \multirow[t]{3}{*}{ ASDM } & 2010 & 14.150 .154 .000 & 308.122 .516 .000 & 1,375824519 & 1 \\
\hline & 2011 & 27.542 .340 .000 & 954.710 .771 .000 & 5,098688085 & 1 \\
\hline & 2012 & 28.742 .700 .000 & 996.178 .690 .000 & 4,684281183 & 1 \\
\hline \multirow[t]{3}{*}{ ASJT } & 2010 & 12.006 .616 .448 & 182.571 .015 .455 & 0,72755689 & 1 \\
\hline & 2011 & 11.439 .181 .359 & 241.798 .783 .912 & 2,068312066 & 1 \\
\hline & 2012 & 11.772 .711 .856 & 189.137 .638 .694 & 1,175975259 & 0 \\
\hline \multirow[t]{3}{*}{ ASRM } & 2010 & 24.382 .856 .423 & 457.415 .496 .791 & 2,227943967 & 1 \\
\hline & 2011 & 25.835 .982 .600 & 810.254 .708 .119 & 4,929406101 & 1 \\
\hline & 2012 & 33.042 .956 .959 & 1.070 .925 .850 .176 & 5,671880771 & 1 \\
\hline \multirow[t]{3}{*}{ LPGI } & 2010 & 54.058 .755 .817 & 883.222 .640 .369 & 0,271838412 & 1 \\
\hline & 2011 & -18.750 .583 .286 & 956.657 .189 .094 & 0,451911315 & 1 \\
\hline & 2012 & 353.836 .893 .689 & 1.447 .602 .269 .215 & 0,448062824 & 1 \\
\hline \multirow[t]{3}{*}{ MREI } & 2010 & 46.002 .636 .156 & 445.082 .524 .536 & 1,442415305 & 0 \\
\hline & 2011 & 63.018 .466 .380 & 616.185 .465 .577 & 1,616050488 & 1 \\
\hline & 2012 & 98.010 .518 .366 & 779.759 .863 .615 & 1,422362539 & 1 \\
\hline \multirow[t]{3}{*}{ PNIN } & 2010 & 575.848 .000 .000 & 9.358 .982 .000 .000 & 0,710167119 & 0 \\
\hline & 2011 & 1.036 .941 .000 .000 & 11.639 .940 .000 .000 & 0,450886 & 0 \\
\hline & 2012 & 1.264 .168 .000 .000 & 13.059 .093 .000 .000 & 0,401394004 & 1 \\
\hline \multirow[t]{3}{*}{ PNLF } & 2010 & 745.262 .000 .000 & 8.304 .062 .000 .000 & 0,437351153 & 0 \\
\hline & 2011 & 887.621 .000 .000 & 10.526 .123 .000 .000 & 0,467279406 & 1 \\
\hline & 2012 & 1.111 .486 .000 .000 & 11.753 .772 .000 .000 & 0,415850562 & 1 \\
\hline
\end{tabular}

Sumber: Bursa Efek Indonesia, 2014 Data diolah.

Pada tabel diatas Ketepatan waktu menyampaikan laporan keuangan ( T. Waktu) adalah perusahaan yang memiliki ketepatan waktu (menyampaikan laporan keuangannya kurang 
dari 90 hari setelah akhir tahun atau sebelum tanggal 30 Maret) masuk kategori 1 dan perusahaan yang tidak tepat waktu (menyampaikan laporan keuangannya lebih dari 90 hari setelah akhir tahun atau setelah tanggal 30 Maret) masuk kategori 0. Untuk memperoleh gambaran tentang 33 data tersebut dilakukan olah data secara statistik deskriptif dan hasilnya dapat dilihat sebagai berikut:

Tabel 3

\begin{tabular}{|c|c|c|c|c|c|}
\hline \multicolumn{6}{|c|}{ Descriptive Statistics } \\
\hline & $\mathrm{N}$ & Minimum & Maximum & Mean & Std. Deviation \\
\hline Profitabilitas & 33 & -18750583286 & $\begin{array}{r}1264168000 \\
000\end{array}$ & $\begin{array}{r}2.10 \mathrm{E} 1 \\
1\end{array}$ & $3.677 \mathrm{E} 11$ \\
\hline Uk.Perusahaan & 33 & 126549735522 & $\begin{array}{r}1305909300 \\
000 \quad 0\end{array}$ & $\begin{array}{r}2.53 \mathrm{E} 1 \\
2\end{array}$ & $4.025 \mathrm{E} 12$ \\
\hline Debt to equity & 33 & .272 & 5.672 & $\begin{array}{r}1.7431 \\
8\end{array}$ & 1.471424 \\
\hline $\begin{array}{l}\text { Valid N } \\
\text { (listwise) }\end{array}$ & 33 & & & & \\
\hline
\end{tabular}

Dari tabel diatas diperoleh gambaran tentang data yang dihimpun yaitu; untuk profitabilitas angka tertinggi adalah Rp.1.264.168.000.000 yaitu PT. Panin Insurance, Tbk tahun 2012, dan angka terendah adalah (Rp.18.750.583.286) yaitu PT. Lippo General Insurance, Tbk, tahun 2011, sedangkan rata-rata adalah Rp.210.000.000.000. Untuk Ukuran Perusahaan angka tertinggi Rp.13.059.093.000.000 terjadi pada PT. Panin Insurance, Tbk pada tahun 2012, dan angka terendah Rp.126.549.735.522 terjadi pada PT. Asuransi Harta Aman Pratama, Tbk ditahun 2010, sedangkan rata-rata Rp.2.530.000.000.000. Untuk debt to equity ratio angka tertinggi 5,672 terjadi pada PT. Asuransi Ramayana, Tbk ditahun 2012, dan angka terendah 0.272 yaitu PT. Lippo General Insurance, Tbk pada tahun 2010, sedangkan rata-rata 1.74318 .

\subsection{Pengujian Kualitas Data}

\section{Uji Heteroskedastisitas}

Uji Heteroskedastisitas digunakan untuk mengetahui ada atau tidaknya ketidaksamaan dari residual pada model regresi. Pada pembahasan ini dilakukan uji heteroskedastisitas dengan menggunakan Uji Spearman's rho, yaitu mengkorelasikan nilai residual (Unstandardized residual) dengan masing-masing variabel independen. Jika signifikansi korelasi kurang dari 0,05 maka pada model regresi terjadi masalah heterokedastisitas. (Duwi 
Prayitno, 2010:84). Pada penelitian ini penulis melakukan dua pengujian regresi (karena masing-masing variabel independent memiliki dua indikator). Hasil pengujian tersebut adalah sebagai berikut:

Tabel 4

Hasil Uji Heterokedastisitas

\begin{tabular}{|c|c|c|c|c|c|c|c|}
\hline \multicolumn{8}{|c|}{ Correlations } \\
\hline & & & $\begin{array}{c}\text { Profita- } \\
\text { bilitas }\end{array}$ & $\begin{array}{c}\text { Ukuran } \\
\text { Perusahaan }\end{array}$ & $\begin{array}{c}\text { Debt to } \\
\text { equity }\end{array}$ & $\begin{array}{c}\text { Ketepatan } \\
\text { waktu }\end{array}$ & $\begin{array}{l}\text { Unstan- } \\
\text { dardized } \\
\text { Residual }\end{array}$ \\
\hline \multirow[t]{15}{*}{$\begin{array}{l}\text { Spearman's } \\
\text { rho }\end{array}$} & \multirow[t]{3}{*}{$\begin{array}{l}\text { Profitabilit } \\
\text { as }\end{array}$} & $\begin{array}{l}\text { Correlation } \\
\text { Coefficient }\end{array}$ & 1.000 & $.741^{* *}$ & $-.467^{* *}$ & -.248 & -.039 \\
\hline & & $\begin{array}{l}\text { Sig. (2- } \\
\text { tailed) }\end{array}$ & & .000 & .006 & .165 & .829 \\
\hline & & $\mathrm{N}$ & 33 & 33 & 33 & 33 & 33 \\
\hline & \multirow[t]{3}{*}{$\begin{array}{l}\text { Ukuran } \\
\text { Perusahaan }\end{array}$} & $\begin{array}{l}\text { Correlation } \\
\text { Coefficient }\end{array}$ & $.741^{* *}$ & 1.000 & $-.387^{*}$ & -.140 & .181 \\
\hline & & $\begin{array}{l}\text { Sig. (2- } \\
\text { tailed) }\end{array}$ & .000 & & .026 & .436 & .314 \\
\hline & & $\mathrm{N}$ & 33 & 33 & 33 & 33 & 33 \\
\hline & \multirow[t]{3}{*}{$\begin{array}{l}\text { Debt to } \\
\text { equity }\end{array}$} & $\begin{array}{l}\text { Correlation } \\
\text { Coefficient }\end{array}$ & $-.467^{* *}$ & $-.387^{*}$ & 1.000 & .169 & -.335 \\
\hline & & $\begin{array}{l}\text { Sig. (2- } \\
\text { tailed) }\end{array}$ & .006 & .026 & & .347 & .057 \\
\hline & & $\mathrm{N}$ & 33 & 33 & 33 & 33 & 33 \\
\hline & \multirow[t]{3}{*}{$\begin{array}{l}\text { Ketepatan } \\
\text { waktu }\end{array}$} & $\begin{array}{l}\text { Correlation } \\
\text { Coefficient }\end{array}$ & -.248 & -.140 & .169 & 1.000 & $.668^{* *}$ \\
\hline & & $\begin{array}{l}\text { Sig. (2- } \\
\text { tailed) }\end{array}$ & .165 & .436 & .347 & & .056 \\
\hline & & $\mathrm{N}$ & 33 & 33 & 33 & 33 & 33 \\
\hline & \multirow{3}{*}{$\begin{array}{l}\text { Unstandard } \\
\text { ized } \\
\text { Residual }\end{array}$} & $\begin{array}{l}\text { Correlation } \\
\text { Coefficient }\end{array}$ & -.039 & .181 & -.335 & $.668^{* *}$ & 1.000 \\
\hline & & $\begin{array}{l}\text { Sig. (2- } \\
\text { tailed) }\end{array}$ & .829 & .314 & .057 & .000 & \\
\hline & & $\mathrm{N}$ & 33 & 33 & 33 & 33 & 33 \\
\hline
\end{tabular}

Dari output Coefficient di atas, dapat dilihat korelasi antara profitabilitas, ukuran perusahaan, dan debt to equity ratio terhadap unstandardized residual nilai signifikansinya lebih dari 0,05, maka dapat dikatakan bahwa pada model ini tidak ada masalah heterokedastisitas. 


\section{Uji Multikolinieritas.}

Uji Multikolinieritas ini untuk mengetahui apakah terdapat inter korelasi yang sempurna diantara beberapa variabel bebas yang digunakan dalam model. Hasil uji multikolinearitas pada penelitian ini juga dibagi berdasarkan dua indikator, yaitu sebagai berikut:

Tabel 5

Hasil Uji Moltikolinearitas

\begin{tabular}{|c|c|c|c|c|c|c|c|}
\hline \multicolumn{8}{|c|}{ Coefficients $^{\mathrm{a}}$} \\
\hline \multirow[b]{2}{*}{ Model } & \multicolumn{2}{|c|}{$\begin{array}{l}\text { Unstandardized } \\
\text { Coefficients }\end{array}$} & \multirow{2}{*}{$\begin{array}{c}\begin{array}{c}\text { Standardized } \\
\text { Coefficients }\end{array} \\
\text { Beta }\end{array}$} & \multirow[b]{2}{*}{$\mathrm{t}$} & \multirow[b]{2}{*}{ Sig. } & \multicolumn{2}{|c|}{$\begin{array}{l}\text { Collinearity } \\
\text { Statistics }\end{array}$} \\
\hline & $\mathrm{B}$ & Std. Error & & & & Tolerance & VIF \\
\hline 1 (Constant) & .849 & .132 & & 6.458 & .000 & & \\
\hline Profitabilitas & $1.206 \mathrm{E}-12$ & .000 & 1.132 & 1.297 & .205 & .039 & 25.914 \\
\hline $\begin{array}{l}\text { Ukuran } \\
\text { Perusahaan }\end{array}$ & $-1.335 \mathrm{E}-13$ & .000 & -1.372 & 1.606 & .119 & .040 & 24.805 \\
\hline Debt to equity & .031 & .052 & .116 & .600 & .553 & .782 & 5.279 \\
\hline
\end{tabular}

a. Dependent Variable: Ketepatan waktu

Dari output olah data di atas diketahui pada kolom VIF nilainya kurang dari 5, maka dapat disimpulkan bahwa pada model regresi ini tidak ditemukan adanya masalah multikolinearitas.

\subsection{Uji Hipotesis}

Uji hipotesis dilakukan dengan menggunakan model regresi logistik guna mengetahui pengaruh profitabilitas, ukuran perusahaan, dan debt to equity ratio terhadap ketepatan waktu penyampaian laporan keuangan dengan rumusan :

$\operatorname{Ln}(\mathrm{TL} / 1-\mathrm{TL})=\mathrm{a}+\mathrm{b}_{1} \mathrm{X}_{1}+\mathrm{b}_{2} \mathrm{X}_{2}+\mathrm{b}_{3} \mathrm{X}_{3}+$ et

$\operatorname{Ln}(\mathrm{TL} / 1-\mathrm{TL})=$ Dummy variabel ketepatan waktu (kategori 1 untuk perusahaan yang tepat waktu dan kategori 0 untuk perusahaan yang tidak tepat waktu).

a

$=$ Konstanta

$\mathrm{b}_{1}, \mathrm{~b}_{2} \quad=$ Koefisien regresi,

$\mathrm{b}_{3} \mathrm{X}_{1}, \mathrm{X}_{2}, \mathrm{X}_{3}=$ Profitabilitas $\left(\mathrm{X}_{1}\right)$, Ukuran Perusahaan $\left(\mathrm{X}_{2}\right)$ dan $\mathrm{X}_{3}$

Debt to Equity ratio $\left(\mathrm{X}_{3}\right)$

et

$$
\text { = error term. }
$$

1. Menilai keseluruhan model (Overall Model Fit)

Untuk menilai keseluruhan model diawali dengan melihat bagian beginning sebagai berikut: 
Tabel 6

Iteration History ${ }^{a, b, c}$

\begin{tabular}{|c|c|c|}
\hline \multirow[b]{2}{*}{ Iteration } & \multirow{2}{*}{$\begin{array}{l}-2 \text { Log } \\
\text { likelihood }\end{array}$} & $\begin{array}{c}\text { Coefficient } \\
\text { s }\end{array}$ \\
\hline & & Constant \\
\hline Step 01 & 31.569 & 1.273 \\
\hline 2 & 31.294 & 1.489 \\
\hline 3 & 31.293 & 1.504 \\
\hline 4 & 31.293 & 1.504 \\
\hline
\end{tabular}

a. Constant is included in the model.

b. Initial -2 Log Likelihood: 31,293

c. Estimation terminated at iteration number 4 because parameter estimates changed by less than ,001.

Berdasarkan tabel 6 diketahui nilai statistik -2 Log likelihood yang masih hanya menggunakan konstanta (c) adalah 31,293 sedangkan saat kita sudah melibatkan variabel bebasnya (descretionary accrual), nilai -2 Log Likelihood adalah 27,086. Dapat dilihat pada tabel 7 sebagai berikut:

Tabel 7

Model Summary

\begin{tabular}{|l|c|c|c|}
\hline Step & $\begin{array}{c}-2 \text { Log } \\
\text { likelihood }\end{array}$ & $\begin{array}{c}\text { Cox \& Snell } \\
\text { R Square }\end{array}$ & $\begin{array}{c}\text { Nagelkerke R } \\
\text { Square }\end{array}$ \\
\hline 1 & $27.086^{\mathrm{a}}$ & .120 & .195 \\
\hline
\end{tabular}

a. Estimation terminated at iteration number 5

because parameter estimates changed by less than , 001 .

Hal ini menunjukkan adanya penurunan nilai saat variabel bebas sudah dimasukkan yaitu sebesar 31,293 - 27,086 = 4,207 (angka ini dapat dilihat pada tabel Omnibus Tests of Coefficients) sebagai berikut:

Tabel 8

Omnibus Tests of Model Coefficients

\begin{tabular}{|rl|r|r|r|}
\hline & & Chi-square & \multicolumn{1}{c|}{ df } & \multicolumn{1}{c|}{ Sig. } \\
\hline Step 1 & Step & 4.207 & 3 & .240 \\
& Block & 4.207 & 3 & .240 \\
& Model & 4.207 & 3 & .240 \\
\hline
\end{tabular}

Penurunan likelihood (-2LL) menunjukkan bahwa model regresi yang lebih baik atau dengan kata lain model yang dihipotesiskan fit dengan data.

2. Koefisien Determinasi (Nagelkerke R Square) 
Cox dan Snell's $R$ Square merupakan ukuran yang mencoba meniru ukuran R2 pada multiple regression yang didasarkan pada teknik estimasi likelihood dengan nilai maksimum kurang dari 1 (satu) sehingga sulit diinterpretasikan. Nagelkerke's $R$ square merupakan modifikasi dari koefisien Cox dan Snell untuk memastikan bahwa nilainya bervariasi dari 0 (nol) sampai 1 (satu). Hal ini dilakukan dengan cara membagi nilai Cox dan Snell's R2 dengan nilai maksimumnya. Nilai Nagelkerke's R2 dapat diinterpretasikan seperti nilai R2 pada multiple regression. Nilai yang kecil berarti kemampuan variabel independen dalam menjelaskan variasi dependen amat terbatas. Nilai yang mendekati satu berarti variabel independen memberikan hampir semua informasi yang dibutuhkan untuk memprediksi variasi dependen.

\section{Menguji Kelayakan Regresi}

Berdasarkan hasil uji dengan Hosmer and Lemeshow Test. Hasilnya, nilai Sig. 0,490 lebih besar dari Alpha 5\% sehingga kita menerima hipotesis nol (secara statistik tidak terdapat perbedaan yang signifikan antara profitabilitas, ukuran perusahaan, dan debt to equity dalam hal ketepatan waktu penyampaian laporan keuangan) sehingga model sudah fit dengan data. Selain itu dengan membandingkan nilai Chi Square hitung Hosmer and Lemeshow Test dengan chi square tabel berikut; 7,444 $<15,507$ (hasilnya tetap menerima hipotesis nol). Sehingga hasil penelitian ini menyatakan tidak ada pengaruh yang signifikan antara profitabilitas, ukuran perusahaan, dan debt to equity ratio terhadap ketepatan penyampaian laporan keuangan pada perusahaan asuransi yang terdaftar di Bursa Efek Indonesia dengan data laporan keuangan tahun 2010 hingga 2012. Nilai Chi Square hitung tersebut dapat dilihat pada tabel 9. sebagai berikut:

Tabel 9

Hosmer and Lemeshow Test

\begin{tabular}{|c|c|c|c|}
\hline Step & Chi-square & $\mathrm{df}$ & Sig. \\
\hline 1 & 7.444 & 8 & .490 \\
\hline
\end{tabular}

Berdasarkan output variabel in the equation yang dapat dilihat pada tabel 4.10 sebagai berikut: 
Tabel 10

Variables in the Equation

\begin{tabular}{|ll|r|r|r|r|r|r|}
\hline & \multicolumn{1}{|c|}{ B } & \multicolumn{1}{|c|}{ S.E. } & \multicolumn{1}{c|}{ Wald } & \multicolumn{1}{c|}{ df } & \multicolumn{1}{c|}{ Sig. } & Exp(B) \\
\hline Step $1^{\mathrm{a}}$ X1 & .000 & .000 & 1.262 & 1 & .261 & 1.000 \\
& X2 & .000 & .000 & 1.754 & 1 & .185 & 1.000 \\
& X3 & .205 & .436 & .220 & 1 & .639 & 1.227 \\
Constant & 1.831 & 1.060 & 2.987 & & 1 & .084 & 6.242 \\
\hline
\end{tabular}

a. Variable(s) entered on step 1: X1, X2, X3.

Maka dapat disusun model penelitian sebagai berikut:

$\mathrm{Y}=1,831+0,205 \mathrm{X}_{3}$

\section{Kesimpulan dan Saran}

\subsubsection{Kesimpulan}

Berdasarkan hasil analisis dan pembahasan, maka dapat ditarik kesimpulan sebagai berikut :

a. Berdasarkan nilai Nagelkerke $R$ Square disimpulkan bahwa variabel profitabilitas, ukuran perusahaan, dan debt to equity hanya dapat berkontribusi atau menjelaskan variabel dependent (ketepatan waktu penyampaian laporan keuangan) sebesar 19,5\%, sedangkan sisanya sebesar $80,5 \%$ dijelaskan oleh variabel lain yang tidak masuk dalam model penelitian ini.

b. Berdasarkan hasil uji dengan Hosmer and Lemeshow Test. Hasilnya, nilai Sig. 0,490 lebih besar dari Alpha 5\% sehingga kita menerima hipotesis nol (secara statistik tidak terdapat perbedaan yang signifikan antara profitabilitas, ukuran perusahaan, debt to equity dalam hal ketepatan waktu penyampaian laporan keuangan) sehingga model sudah fit dengan data. Selain itu dengan membandingkan nilai Chi Square hitung Hosmer and Lemeshow Test dengan chi square tabel berikut; 7,444 $<15,507$ (hasilnya tetap menerima hipotesis nol). Sehingga hasil penelitian ini menyatakan tidak ada pengaruh yang signifikan antara profitabilitas, ukuran perusahaan, debt to equity terhadap ketepatan waktu penyampaian laporan keuangan pada perusahaan asuransi yang terdaftar di Bursa Efek Indonesia dengan data laporan keuangan tahun 2010 hingga 2012. 


\subsection{Saran}

Berdasarkan hasil analisis dan kesimpulan diatas maka saran-saran yang semoga dapat menjadi masukan sebagai berikut:

d. Karena variabel independent berkontribusi atau menjelaskan variabel dependent ketepatan waktu penyampaian laporan keuangan sebesar 19,5\% (sangat kecil), maka penelitian ini masih perlu dilanjutkan guna mencari tahu dan membuktikan keberadaan faktor lain tersebut.

e. Karena profitabilitas, ukuran perusahaan, debt to equity tidak berpengaruh secara signifikan terhadap ketepatan waktu penyampaian laporan keuangan pada perusahaan asuransi di Bursa Efek Indonesia, maka perlu diteliti lebih lanjut mengapa hal ini bisa terjadi.

\section{Daftar Pustaka}

Ang, Robert. 1997. Buku Pintar Pasar Modal Indonesia. Mediasoft Indonesia.

Aktas, R. \& Kargin, M. (2011). Timeliness of reporting and the quality of financial information International research journal of finance and economics. 63, 71-77.

Bandi dan Hananto, Tri, Santoso. 2000. Ketepatan Waktu atas Laporan Keuangan Perusahaan Indonesia. Simposium Nasional Akuntansi II Ikatan Akuntan Indonesia, h66-75.

Baridwan, Zaki, 1997. Intermediate Accounting. Edisi Ketujuh. Cetakan Kelima. Yogyakarta : BPFE.

Ghozali, I. dan Chariri, A. 2007, Teori Akuntansi. Semarang: Badan Penerbit UNDIP.

Hanafi, Mamduh. 2004. Manajemen Keuangan. Yogyakarta: BPFE-Yogyakarta.

Hartono. 2005. Hubungan Teori Signalling Dengan Underpricing Saham Perdana di BUrsa Efek Jakarta. Jurnal Bisnis dan Manajemen: pp 35-48

Hendriksen, Eldon S. dan Michael F. Van Breda. 2000. Teori Akunting (Terjemahan). Edisi Kelima. Buku Kesatu. Batam Centre: Interaksara.

Hilmi, Utari. dan Ali, Syaiful. 2008.Analisis Faktor-Faktor yang Mempengaruhi Ketepatan Waktu Penyampaian Laporan Keuangan . Simposium Nasional Akuntansi XI Ikatan Akuntan Indonesia. h.1-22.

Iskandar, Vidia. 2003 . Pengaruh Profitabilitas Perusahaan Terhadap Ketepatan Waktu Pelaporan Keuangan Dengan Opini Audit Sebagai Moderating Variabel Perusahaan Manufaktur. Universitas Gajah Mada.

Keputusan Direksi PT BEJ Nomor Kep-307/BEJ/07-2004.

Keputusan Ketua Badan Pengawas Pasar Modal dan Lembaga Keuangan Nomor 40/BL/2007

Peraturan Nomor. X.K.2, Lampiran Keputusan Ketua BAPEPAM dan LK Nomor. KEP$346 / \mathrm{BL} / 2011$ 
Raharja, Budi. 2001. Akuntansi dan Keuangan Untuk Manajer Nonkeuangan. Edisi Pertama. Cetakan Pertama. Yogyakarta: Penerbit Andi.

Qomariyah, Suparno, Rahmawati. 2007. "Pengaruh Asimetri Informasi Terhadap Praktik Manajemen Laba pada Perusahaan Perbankan Publik yang Terdaftar di Bursa Efek Jakarta."Jurnal Riset Akuntansi Indonesia, Vol.10, No.3, h.68-85

Rahmat ,Saleh dan Susilowaty. 2004. Studi Empiris Ketepatan Waktu Pelaporan Keuangan. Jurnal Bisnis Strategi, h. 66-80.

Srimindarti Ceacilia. 2008. Ketepatan Waktu Pelaporan Keuangan. Fokus Ekonomi, Vol. 7, No.1, h.15-21

Supriyati dan Rolinda, Yuliasri.2007. Analisis Faktor-Faktor yang Mempengaruhi audit Delay, Vol.10, No.3, h.109-121

Suwardjono, 2005. Teori Akuntansi: Perekayasaan Pelaporan Keuangan (Edisi III). Yogyakarta: BPFE

Undang-undang Republik Indonesia No. 8 Tahun 1995, tentang Pasar Modal

Weston, F. dan E. Bringham.1998. Dasar- Dasar Manajemen Keuangan. Jakarta: Erlangga. 